\title{
Ideas-Heroes in the Story Pure Monday by Ivan Bunin
}

\author{
Olga V. Bogdanova* \\ St. Petersburg State University \\ 7/9 Universitetskaya Embankment, \\ St. Petersburg, 199034, Russia
}

Received 10.01.2017, received in revised form 25.02.2017, accepted 29.04.2017

On the basis of comparing the texts of the story Pure Monday (1944) and the religious-philosophical treatise The Liberation of Tolstoy (1937), the article offers a new perspective on the understanding of the philosophical structure of the novel from the series Dark Alleys. The article states the dependence of the ideological and figurative system of the story on the philosophy of death ("the philosophy of leaving") by L. Tolstoy. The author argues that if the plot of the story is a love story between him and her, then according to the conducted analysis at the level of the reflection of the philosophical ideas Bunin's heroes are the personification of the abstract love of the artist for the thoughts and ideas of the preceding writers. The image of the heroine of Pure Monday is the idea-personification of Bunin's love to the late philosophical views of Tolstoy. The image of the main hero is the reflection of ideas about the Pushkin's world, his "Onegin type" embodied in his character. The conflict of different life philosophies becomes a "condition" of the failed love of the heroes.

Keywords: the history of Russian literature of the 20th century, prose, I.A. Bunin, Pure Monday, philosophical structure, figurative system.

DOI: 10.17516/1997-1370-0072.

Research area: philology.

Introduction to the study. As is wellknown, the first publication of the story Pure Monday appeared in The New Journal (New York) in 1945 (Book 10). The following year, the story was included in the book Dark Alleys (Paris, 1946). The first responses to the story (the articles of I. Il'in, V. Vil'ginskii, Iu. Ivask, M. Kreps, Iu. Stepun, Iu. Trubetskoi, etc.) expressed the idea that Pure Monday was devoted to the theme of love, especially since it was included in Bunin's anthology of love, in the series of stories Dark Alleys (1937-1944, 1953).

Statement of the problem. Indeed, the main motive lines that permeate the story are covered with lyrical (or dramatic) reflections of the author and the hero about love, about the mystery of the alien soul, about the complexity and mysteriousness of human relations. However, the comparison of the text of the story studied in different aspects with Bunin's philosophical treatise The Liberation of Tolstoy (1937) allows

(C) Siberian Federal University. All rights reserved

* Corresponding author E-mail address: olgabogdanova03@mail.ru 
us to look at the heroes of the story differently and see the mental origins of their appearance and incarnation.

Methodology. The analysis is based on the synthesis of the fundamental methods and principles of scientific research, among which are primarily the contextual (the methods of historical, comparative, intertextual analysis), phenomenological (including biographical), formal-structural (typological, poetic) methods in their interrelationship and additionality.

The problem-analytical part. The narration in Pure Monday is carried out from the first person, through the subjective-personal perception of the hero participating in the depicted events. Moreover, the chronotope of the story "doubles" or even "triples", multiplies and is compressed, since the main events occur in 1913, the final circumstances are related to the passage of two years, that is, they fall at the end of 1914, while the moment of memories of the so-called "conditional present" is shifted to other dates, which are more or less correlated with the events in Moscow in the 1910s. Thus, if we connect the temporal structure of the text with the time of writing the story (the textual 1944 year), then the "conditional present" can be pushed back into the past for about 30 years. The narrative from the first person (doubling or tripling) allows subjecting the depicted story events, giving them a color of authenticity and vitality, while the universal collision of the relationship between him and her gives an opportunity to comprehend the "eternal" questions of human existence artistically and aesthetically, to trace the vectors of a personal formation of characters. The narration from the person of the hero, who is enthusiastically in love with the "strange" heroine, brings the female image to the fore, intentionally putting her at the center of the narrative.

Critics are inclined to talk about the purposefulness of the main character, about her spiritual concentration and in the end about integrity. Thus, O.N. Mikhailov writes, "In her strange deeds, we feel the significance of the character, the rarity and the 'selectivity' of nature...” (Mikhailov, 2002: 11). Meanwhile, from the first lines of the narrative, in the image of the protagonist, certain "oddities" and contradictions are constantly emphasized. The situational inconsistency of the behavior of the heroine is revealed at the very beginning of the narration. In the image of the heroine, the features of the majestically sophisticated "kingmaiden" (Bunin, 2002: 215) and simultaneously Tver (or Astrakhan), almost Custodian, merchant (Bunin, 2002: 207) enjoying the oil pancakes "overly topped with sour cream" (Bunin, 2002: 212) seem to blend. On the one hand, the heroine leads a seemingly idle and bohemian way of life, "every month she did not go out at all and did not leave the house for three or four days, she lay and read" (Bunin, 2002: 208) or went to watch "a new production of the Artistic Theater", visited the Art Circle, listened to "the lecture of Andrei Belyi" (Bunin, 2002: 208), but on the other hand, she "studied at some kind of female courses" (Bunin, 2002: 206). Next to the modern naiad, there is a type of an emancipated student, ready ("for some reason") to uphold the forefront views and women's rights, to demand the freedoms and benefits of society.

In the story, first of all devoted to the theme of love, the character and consciousness of the ambiguous and mysterious heroine are permeated with the main and decisive dilemma that is the clash of pure love and sinful love, exalted love and carnal love, love for God and love for man, ie, the search for the true and only love. And this main love of the heroine is faith, the monastery, God. It is not accidental that O.N. Mikhailov says that "in love a woman, Bunin's heroine, $<_{\ldots} .>$ is higher, more spiritual than the hero" (Mikhailov, 2002: 3). Therefore, traditionally, researchers 
highly appreciate the decision of the heroine to go to the monastery, join the spiritual truth and find oneself through the divine service. However, in the behavior of the heroine, the moment that is important for the understanding of her image remains "mystery": it is about how the heroine makes her choice, which way she chooses, why she should be the wife of an earthly man before she is called the "Christ's wife". Before touching the "high", not even under the influence of a feeling or a temptation but deliberately, the heroine gives herself to the "low". The "strange" behavior of the female character does not find a casual motivation in the text, remains a kind of "riddle".

As for the image of the hero, he does not attract a concentrated attention of criticism. The researchers hold to the view that the hero is passive and subject to influence, that he is weak and submissive. O.N. Mikhailov believes, “... thirty-eight short stories of Dark Alleys give a great variety of unforgettable female types, such as Rusia, Antigona, Tania, Galia Ganskaia, Polia (Madrid), the heroine of Pure Monday. Close to this inflorescence, male characters are much less expressive. They are less diverse, sometimes only indicated and, as a rule, static. The heroes are characterized more indirectly, reflected in connection with the physical and mental appearance of a woman whom they love and who occupies a self-sufficient place in the story". (Mikhailov, 2002: 8). And this is partly true. It seems the narrator does narrate exactly about the heroine, but at the same time (with all certainty) first of all about himself, about his love, about his failed hopes and deep spiritual changes. The visible and justifiable statement of the heroine in the center of narration is actually superficial, almost imaginary, for in fact the hero refers to the "confessional" form of the narrative about himself. The title of the story that is Pure Monday is directly connected not only with the image and fate of the heroine, as researchers usually treat it (Nikolina, 1996: 82), but also with the image of him, the heronarrator.

A lot has been said about the opposition of the heroes in the criticism. A special attention was paid to the antinomy of the east and the west, which found realization in the images of the main characters of the story. One of the first to make a detailed and convincing analysis of these motives was L.K. Dolgopolov (Dolgopolov, 1973: 93-109). Eastern features in the portrait of the hero (Bunin, 2002: 206) embody not only the singularity of the Russian type, but also, from the artistic point of view, expose the hero's closeness to his chosen one, the eastern "shamakhan queen". Youth, beauty and orient features seem to bring together the heroes, motivate their mutual affection and enthusiastic love of the hero. At the same time, L.K. Dolgopolov and his followers qualify the main character as a man of the Western world and European traditions rather than the eastern ones, in contrast to the "utterly" Eastern heroine. And this is true, especially against the background of the chronotoptic antithesis embodied in the heroes that is the opposition of the modernist world and the classical world, "the present century" and "the past century".

The "conflict" state of the chronotop of the story Pure Monday is set by Bunin from the first lines of the narrative. A landscape sketch revealing the narrative, a priori, establishes the plot world duality, programming insoluble contradictions in the environment and in the relations of the heroes (Bunin, 2002: 206). Borderlessness of the time of day (evening $\leftrightarrow$ day), visual-sensory antinomies (cold $\leftrightarrow$ warm, dark $\leftrightarrow$ light, heavily $\leftrightarrow$ cheerfully), imageries (crowded trams $\leftrightarrow$ single passers-by), oxymoronic constructions ("lighted up in a cold way") form a contradictory two-part structure of the future narration , "conflicting" interrelations of the main characters. 
From the very first words of the story, the hero appears sincere and direct, able to notice details and nuances subtly and poeticly, not inclined to subjectivize and deform them. He "alive, always ready for a happy smile, for a good joke", does not hide "simple gaiety", with youthful simplicity, says "what comes to mind" (Bunin, 2002: 207). Unlike the heroine, he is available to surprise ("surprised", "even more surprised" (Bunin, 2002: 210), "amazed" (Bunin, 2002: 216)). The hero is like a "natural" man, for whom the world around is full of life, bright impressions, tangible tastes, colorful sounds, saturated smells (Bunin, 2002: 209). For him, the river Moscow is "snow-gray" (Bunin, 2002: 209), the evening star is "green" (Bunin, 2002: 206), the jackdaws reflected in the golden domes of the temple of Christ the Savior are "bluish" (Bunin, 2002: 209), in the setting sun the trunks of trees "turn pink" (Bunin, 2002: 212), the smell of the heroine's hair is "spicy" (Bunin, 2002: 210).

The hero is immersed in the ideals and secular codes of Moscow in the 1910s, the adherence to which raised the woman on a pedestal, dictated the admiration for the ideal (almost Blok's) of the "beautiful lady." However, the principle of the behavior of Bunin's secular rake is not just "ritual"; it is the inner essence of a young and passionate hero - he is in love with enthusiasm and inspiration. It is noteworthy that "soon" after meeting with the heroine, he proposes to her (Bunin, 2002: 209). It can be said about the hero truly in a Pushkin's manner, "he is in a hurry to live as well as to feel!" And even the refusal of the heroine does not greatly upset him (Bunin, 2002: 209): the character with an open mind and an easy heart holds out the hope for mutual love, even in torment (of love) he sees only happiness (Bunin, 2002: 210). His love sorrow (again) is light in a Pushkin's manner, "I'm sad and light ..."

The hero-narrator does not say much about himself, does not mention his education.
However, the books brought to the heroine ("new books by Hoffmannstahl, Schnitzler, Tetmajer, Przybyszewski" (Bunin, 2002: 207)) seem to be familiar to the hero (his question about Fiery Angel by V. Briusov or the mention of L. Andreev is not accidental). The meeting of the heroes at the party of Andrei Belyi demonstrates that he is a frequenter of fashionable meetings, public appearances, theatrical "skits", new theatrical performances and concerts. He revolves in the circle of "famous actors" (Bunin, 2002: 207), is next to Stanislavskii, Kachalov, Sulerzhitskii, listens to Shaliapin. He talks and knows much about Moscow, Astrakhan, thinks about Persia and India. Not only the heroine, but he also knows Moscow's temples, chapels, monasteries and cemeteries ("Is this famous schismatics?" (Bunin, 2002: 211)). He reflects on the "strange city" of Moscow, "the Okhotny Ryad, Iverskaia street, Basil the Blessed, <..> Spas-na-Boru" (Bunin, 2002: 209). The hero is observant and thin, he guessed "something Kyrgyz in the points of the towers on the Kremlin walls ...", sees the "Italian" roots of the old Moscow cathedrals (Bunin, 2002: 209), does not accept the "too new crowd of Christ the Savior" in an aesthetically evaluating way (Bunin, 2002: 209). With no less freedom than the heroine, he is able to quote ancient texts (Bunin, 2002: 213). With Pushkin's frivolity, he could have repeated, "We all learned something and somehow little by little..."

The confessional form of narration narrows the breadth and limits the multiplicity of portrait (external) characteristics that the hero is endowed with. However, one detail of the external appearance of the character is repeated twice in the text (three times in variable form), persistently accented and intertextual. And the famous Onegin "beaver collar" is also Pushkin's one (Bunin, 2002, 207: 215). Through the distinct and easily identifiable image-marker, the author makes it possible to guess not only the genealogy 
of the hero, those "western" roots that the critic talked about, but also includes his image in the semantically significant field of classical literary predecessor characters. The Bunin's hero appears in the image of a young Onegin, a secular capital's rake, a representative of the "golden youth", carried away, in love, not yet touched by the fashionable "split" or "melancholy", wholly enjoying life, youth, prosperity, happiness, love. The entire image of the hero is permeated with “light (Pushkin's) moods" (Bunin, 2006-2007: 8), "with his words I pour out my fictitious youthful love" (Bunin, 2006-2007: 10), Bunin seems to admit. And against the emerging "PushkinOnegin background", the details of the works of Lev Tolstoy, another classic by the time and by the spirit, which are scattered throughout the text, become clearer and more distinctly and are revealed in a more informative way.

Researchers repeatedly paid attention to the speech features and details of the portrait of Andrei Bolkonsky, Pierre Bezukhov, Lisa, Platon Karataev, Anna Karenina, and Levin, which in the story Pure Monday labeled one or another character, episode, situation. However, the meaning of these "signs" remained unclear. Now in the comparison of Pushkin and Tolstoy's beginnings the nature of the love "conflict" of heroes appears more clearly, the essence of their sensual opposition is also more clearly revealed. The controversy of Pushkin and Tolstoy deciphers the hero's misunderstanding of the heroine (his numerous "for some reason", "it's not clear why"), as well as her inability to understand him ("you can not understand as I do <... ", "you can not imagine $<$... " (Bunin, 2002: 213), and others). The passionate and genuinely lively Pushkin sense of immersion in love and dissolution in it collides with (late) Tolstoy (in the times of the Kreutzer Sonata) "abstinence" and "lifelessness" (Bunin, 2002: 216). Behind the antinomies "East $\leftrightarrow$ West", "masculine $\leftrightarrow$ feminine" ("he $\leftrightarrow$ she") another antithetical pair of "Pushkin $\leftrightarrow$ Tolstoy" appears, the juxtaposition of whose names points to Bunin's ambiguous attitude to love.

In The Liberation of Tolstoy, Bunin speaks of Tolstoy's division of life into "three phases", "Man experiences three phases $<\ldots>$ In the first phase, he lives only for his passions: food, drink, hunting, women, vanity, pride, and life is full. $<_{\text {... }}>$ Then $<_{\text {... }}>$ it can be an interest in benefit of people, all people, humanity ... $<\ldots><$ The third phase $>$ is the service to God, the fulfillment of his will in relation to that his essence that is in me. $<_{\ldots}>>$ This desire for the purity of the divine..." (Bunin, 1996: 18). According to Bunin (after Tolstoy), his hero passed the "Pushkin" phase of his "passions": eating, drinking, women, vanity, pride (hence is so generous and abundant enumeration and depiction of restaurants, dishes, gourmands in the story) and approached to the entrance to the "second phase". Meanwhile, the heroine of Pure Monday has already reached the third "Tolstoy" phase, "divine love", according to Tolstoy. Thus, in these Tolstoy-Pushkin coordinates the ideological and structural collision of the story is clearly revealed: the heroes could not be together, not because Bunin "shows its 'all-powerful love's'> inaccessibility" (Garmash, 2004: 9), as some researchers believe, but because he and she lived different phases of life, incompatible and multidirectional. The mental coordinates of the chronotopes of the heroes are spaced apart, the vector nature of their movements is differentiated, they intersected at some "point of convergence", but could not coincide absolutely and unite: the heroine turned out to be "Tolstoy's", the hero was "Pushkin's".

The appeal to Tolstoy makes us remember that in the second half of the 1930s Bunin worked on a book of memoirs and reflections that was the philosophical and religious treatise The Liberation of Tolstoy, where, following the great old man and along with him, he was looking for 
ways to "overcome" and "liberate", "pass away" and "realize" death. P.M. Bitsilli wrote, "The main theme of Bunin's book is the interpretation of that last stage in the life of Tolstoy, which is usually called "withdrawal". Bunin calls it "liberation". Liberation from what? < ...> From all that constitutes the main subject of the interest of "psychologizing" or moralizing biographers? No, from “Death" ... “(Bitsilli, 2000: 427). In Bunin's view, the condition of "liberation", overcoming death and getting rid of it (according to Tolstoy) was the entry into the "third phase" of human existence that is the "striving for the purity of the divine" when "the interest in private life disappeared" and "the religious interest" grew up, when "consciousness and human life merges with the One Life, with the One Self." (Bunin, 1996: 14-15). At this stage, the "acute sensation of the Universe" is associated with the abandonment of the "non-binding laws" of personal, including family life, with the rejection of the laws of "bodily existence", the rejection of carnal manifestations of life, the abandonment of the need for procreation. Bunin writes out from Tolstoy's diary, "Help, Father! I hate my nasty flesh, I hate myself (bodily) ... I could not sleep at night. My heart aches without ceasing. I prayed so that $\mathrm{He}$ would deliver me from this life ... Father, break, cast out, destroy the flesh. Help, Father!” (Bunin, 1996: 143). Tolstoy's "exposure", the desire for bodily "nakedness", the departure from life during his lifetime, in Bunin's understanding, was also a way of involvement in eternity and immortality that is the path of return to God and merging with Him. On the way to the "barrenness" of existence, the monastery, according to Tolstoy, is a possible form of human "purification" and an achievable condition of "liberation" in life that is readiness for the conscious "transfer of oneself ... to eternal life", "If there is immortality, then only in impersonality...” (Bunin, 1996: 140).
Even at the first glance at the The Liberation of Tolstoy it is striking that at the formal structural level the text is marked by a kind of "chaotic nature", namely, "the disorder" of the citations quoted, the numerous citation repetitions and the repeated references to the same Tolstoy sentences. Throughout the text, the chronotope "breaks up", it is fragmented. The coordinates of time and space are mobile (then and now, long ago and now, there and here). The artistic reality and actual reality are in contact and diffuse (text and life, literary quotation and author's reflection). Narrative voices multiply and intersect (the "primary" narrator gives way to the "secondary" one, and often to the "tertiary" one). The structural compositional "unformality" is the evidence that the treatise essay on Tolstoy probably was not conceived by Bunin as something unified and integral, but "started" in Bunin's diaries; it's no coincidence that the pages of the Bunin diaries for 1934-1936 are almost empty. However, in connection with the task of comparing The Liberation of Tolstoy with the story Pure Monday, it is not so much the form of the narrative (which is in fact largely diary) that is important, but the leading ideological direction of the work that is an appeal to Tolstoy's religious philosophy.

The idea of the possibility of comparing the texts of The Liberation of Tolstoy and Pure Monday is prompted by one of the first chapters of the treatise, namely the description of the scene of the acquaintance of young Bunin with Tolstoy, the first visit of the beginning writer to the famous old man, which is permeated with the notes of ecstasy and awe, admiration and admiration. The fragment concerns the real events of January 1894, when, in Moscow, the young Bunin decides to visit Tolstoy in his house in Khamovniki (Bunin, 1996: 48-49). The description is "ecstatic, almost ecstatic" (Averin, 2001: 654). But what is more important, 
it surprisingly reminds the beginning of the story in Pure Monday - the same excitement and admiration, the same delight and awe, the same evening and stars, the same love.

It is curious that when describing the meeting in 1894 Bunin presents the classic writer approximately in the image in which he appears in the portrait hanging over the wide Turkish sofa of the heroine of the story. “... big, gray-bearded, as if slightly legged, in a wide, baggy-stitched blouse made of gray paper, in the same pants, more like bloomers." (Bunin, 1996: 49). In the heroine's apartment a portrait hanging on the wall is most likely a reproduction of the famous painting Leo Tolstoy Barefoot, painted by I.E. Repin in 1891. Over the heroine's bed Bunin could have "hung" another portrait, say, painted by the same Repin, entitled Leo Tolstoy (1887), where the famous writer is depicted in dark robes, sitting in a chair with a book in his hand. However, Bunin did not do this: the narrative portrait clearly resembles the image of Tolstoy, formed in the minds of the young Bunin at their first meeting and recorded in an essay-diary.

It is also noteworthy that in the description of the meeting with Leo Tolstoy in the behavior of the writer Bunin accentuates the gesture of an outstretched hand, "... he comes up to me, stretches, or rather throws his big hand in a palmup manner, takes all of mine, gently squeezes it and suddenly smiles with a charming smile." (Bunin, 1996: 49). In Pure Monday one of the most expressive gestures which the heroine is portrayed with is her hand that she invariably stretches out (for the kiss). Gestures are different (especially in the light of gender), but in both cases are marked.

"That" Tolstoy (of 1894) still instructs the young man with the words, "Are you single? Married? You can live with a woman only as a wife without leaving her ever...” (Bunin, 1996: 49). However, the whole subsequent text of The
Liberation in different versions comprehends another maxim of "late" Tolstoy about the need to abandon neighbors, the family, women and children for God's sake. It is this idea that the heroine of the story harbors in herself, stubbornly repeating that she "is not fit" to be a wife, "I'm not fit, I'm not good ..." (Bunin, 2002: 209). The "strangeness" of the heroine becomes understandable if one recognizes that she consistently confesses Tolstoy's views of recent years (the events in the story take place exactly in the 1910s). And then her "dressing up" in a modest "downshifted" student, the mentioned breakfasts in the vegetarian canteen, the rejection of the family and the desire to go to the monastery reveal the ideological roots of her behavior. In this context, she ceases to be perceived as a person blindly following the fashion, but reveals a kinship with the behavior of young "Tolstoyans" who are trying to imitate the idol in everything. Another thing is that the "Pushkin" nature of the hero's image created in the story shades from him, who has not yet reached an understanding of the philosophy of "downshifting", the comprehension of the ideological roots of the heroine in another life phase. For him, the different sides of the nature of the heroine is a kind of theatrical game, for the heroine it is a spiritual search, emerging in the struggle of predilections and contradictions.

In The Liberation Bunin tells how in his youth being carried away by Tolstoyism, he was connected with Tolstoy's book publishing house Mediator. Participating in the distribution of the books of Mediator, according to the narrator, he considered himself then "the brother and associate" of the publishers (Tolstoy), and precisely in connection with Mediator he saw Tolstoy several times, "There $<$ in the Publishing house in Moscow> I saw him several times. Sometimes he came around there, or rather ran in, (for he walked surprisingly easily and quickly) 
and, without taking off his sheepskin coat, sat for an hour or two, surrounded by 'the literary fraternity’ on all sides.” (Bunin, 1996: 51). It is curious, that the same (or very similar) episode also occurs in Pure Monday - the arrival of the hero in the heroine's apartment "from frost", when she orders to sit down beside the sofa, "without taking off the coat" refers to the beginning of the story. Through the expressive detail that is "without taking off the sheepskin coat" (" $<\ldots>$ coat") - the texts of the essay and the story enter into a dialogue (autointertext) and are comparable. And although this gesture in the story is "attributed" not to the heroine, but to the hero, the importance of its presence in the artistic space of the story does not decrease.

In one of the fragments of The Liberation Bunin mentions the musicality of Tolstoy. "Being naturally musical and in his youth fond of playing piano, Lev Nikolaevich was not in any way a musician, but possessed an outstanding sensitivity to music.” (Bunin, 1996: 84). It seems nothing points to coinciding with the story, unless one remembers the heroine's attempts to learn the beginning of Moonlight Sonata on the piano. And that is where a characteristic meta appears, especially if you know that among the favorite works of Tolstoy were the sonatas of Beethoven, familiar to him from childhood (Bunin, 1996: 123). In Pure Monday, Bunin focuses on Beethoven's Moonlight Sonata, and this is symptomatic - as is known, the latter is interpreted by experts as a "monument of unrequited love", the composer's unrequited love for Juliette Guicciardi.

The treatise on Tolstoy says, "He did not like and was sometimes indifferent to something that from my point of view was perfect, for example, Wagner's music $<\ldots>$ When he did not like anything in music too much, for example, Mussorgsky's music, he said, 'It's a shame to listen!"'(Bunin, 1996: 84). And at the lexico- semantic level this quote is priceless; Bunin uses a "related" epithet in the story, trusting it to his heroine, who talks about literature. Answering the question of the main character, "Have you finished reading The Fiery Angel?", the heroine replies, "I've finished watching it. It is so grandiloquent that I feel ashamed to read it." (Bunin, 2002: 208). Relaxed in the speech of the heroine, the comparable epithet of a single word family "shame/ashamed" becomes a signal of Tolstoy's presence.

In The Liberation Bunin recalls Tolstoy's addiction to the gypsies, "The big Tolstoy's garden in Khamovniki in spring rang with laughter, guitars, gypsy songs" (Bunin, 1996: 66). The text of the treatise mentions that Tolstoy's brother Sergei Nikolayevich "was married to a gypsy from the choir" (Bunin, 1996: 68). Against this backdrop, it is quite clear why the heroine of the story gazed intently at the faces of the gypsies, why she listened to gypsy songs with such an attention, "In restaurants outside the city, by the end of dinner ... she asked to call the gypsies, and they entered deliberately noisily, cheekily: in front of the choir, with a guitar on a blue ribbon over his shoulder, an old gypsy was walking in a kazakin with galloons ... She listened to songs with a languid, strange grin...” (Bunin, 2002: 210).

The theatrical strokes of the beginning of the $20^{\text {th }}$ century deserve accentuation. Both in the treatise and in the story, Bunin mentions the Art Theater, the names of theatrical figures, theatrical performances, even "skits". These allusionsmemories can be perceived neutrally as a kind of a sign of time, marked by the names of famous and popular actors and directors of the depicted period. However, The Liberation of Tolstoy mentions the same names as in the story, and almost all of them are accompanied by Tolstoy's evaluation remark either in the perception of the "skits" of the Art Theater, or in connection 
with the "loud" singing of Shaliapin (cf. Heroine, "And why did you suddenly leave Shaliapin's concert yesterday?" "It was very daring" (Bunin, 2002: 209). But especially noteworthy among them is the name of a certain Sulerzhitskii. It seems that the "casual" character is needed in the story only in order to convey the "unusual" psychological state of the heroine: Sulerzhitskii invites the heroine to "Tranblan Polka", and she, to the surprise of the hero, agrees, thus giving out some power of feelings that rage inside on the eve of her "withdrawal". Meanwhile, through The Liberation the mention of the name of L.A. Sulerzhitskii becomes motivated and semantically significant. The treatise on him reports that he "belonged to Tolstoy's house" (Bunin, 1996: 61). And then, it would seem, the "optional" character of the story acquires its "compulsion".

A commonplace in the reflections of the researchers was the reference to the Tolstoy's replica of the hero of the story, "I can not be silent!" (Bunin, 1996: 208), "freely" repeating the title of the Tolstoy's journalistic article I Can not Be Silent (1908). In The Liberation Bunin gives a reference to the title of the same article (Bunin, 1996: 110), when he puts it in a number of other journalistic statements of Tolstoy.

The heroine's rhetoric, her inclination to ask pondering questions, is reflected in the multiplicity of Tolstoy's questions reproduced by Bunin in The Liberation, "Machines to do what? Telegraphs to transmit what? Schools, universities, academies to teach what? Meetings to discuss what? Books, newspapers, to spread information about what? Railways to ride to whom and where? Millions of people gathered together and subordinated to one power to do what? $<\ldots>$ Hospitals, doctors, pharmacies to continue life, but to continue life why?" (Bunin, 1996: 109), the words from the biography Leo Tolstoy and His Wife by T. Polner quoted by Bunin. The stylistics of the rhetoric is distinctively comparable.
The motives of the monastic life, naratively dominant in the story and explicated in the treatise by mentioning the non-embodied intention of Tolstoy to go to the monastery and in the story about his sister Mariia Nikolaevna, a nun (68), deserve attention.

There are a lot of similarities of the external, both visual-figurative and verbal-figurative, order between the texts of The Liberation of Tolstoy and Pure Monday. They are not always essential, they are often typological, sometimes random. However, the thing is that in their totality all together they accumulate the idea of a connection between the texts of the essay and the story; basing on the "objective" similarities, they actualize the closeness of the main ideological perspectives of the works mentioned.

Another quote used by Bunin in the treatiseessay is especially worth mentioning. The prose writer cites the opinion of "some very 'secular' person" not named in the text about Tolstoy (Bunin, 1996: 71). And this quote in a more accurate way than all the others, points to a direct link between the treatise and the story, "Simplicity and royalty, inner elegance and refinement of manners merged in Tolstoy. In his handshake, in the halfgesture, which he used to ask the interlocutor to sit down, in the way he listened, everything was filled with grand-seniorship...” (Bunin, 1996: 71). In these words, one of the most expressive and vivid portrait characteristics of the female character of Pure Monday shows up, namely, her royalty and refinement, which turn out to be the most characterological features of the image of the enigmatic and mysterious heroine.

In other words, the comparison of the texts of The Liberation of Tolstoy and Pure Monday allows us to say that in the space of the artistic story Bunin seems to "object" the philosothemes of the essay diary, namely in the personified "animated" images of him and her he embodies abstract philosophical ideas about life, death, 
love, creates almost "Tolstoy's" parable about the life of the human path and the choice that confronts everyone.

In the mainstream of this statement, the "namelessness" of the heroes, about which the criticism spoke a lot, finds its explanation (Romanenkova, 2014: 126-138). The abstractness of the ideas, "personified" in the images of the hero and the heroine of the story, did not require Bunin to specify and even to some extent would reduce the philosophical content of him and her for him. The nominal (nominative) signs of the heroes are not simply reduced, but deliberately eliminated in connection with the focus on the universality that is the philosophical essence of the ideas embodied by Bunin. Neutral anonymous anthroponyms allowed Bunin to strengthen the perspective of universality of the actualized philosothemes (by Tolstoy).

The above observations allow us to say that the heroes of the story are, in the full sense of the word, heroes-ideas, who were embodied in the life-like images of the artistic reality.

Conclusion. Thus, Tolstoy's love for philosophy expressed in the text of the treatise at the level of an essay-publicistic discourse is transformed in the story into an artistic (figurativeaesthetic) discourse of love for a woman. There is a kind of sublimation (substitution) of philosophy by art, the repression of hard (difficult to perceive) mental maxim about life and death by "facilitated" judgments, transferred into the register of ethical, aesthetic and loving-sensual judgments. The philosophical collision of The Liberation of Tolstoy comes to life and is embodied in the variant of narrative (anthropo) types, transforming the philosophy of thought into the philosophy of image. At the level of artistic narration, the correlation of him and her becomes the "substitute" of mental substitutions such as "the first phase" and "the third phase" (that is "Pushkin-Tolstoy"), revealing love for the latter, personal adoration for his wisdom, philosophical readiness to follow the way of "overcoming" and religious "salvation". However, the mentally ideal path of the ideas of the treatise in the text of the story is transformed, acquiring vividness and vitality in artistic images. The heroine seems to remain an "ideal", but her arrival to the third "phase" is not so simple and straightforward and, as a matter of fact, remains an unknown secret as it is impossible to explain the reasons for the "withdrawal" of the heroine completely, they are hidden in the depths of philosophical doctrine. As for the hero, his transition to the second "phase" after parting with the heroine becomes a sign not so much of the character's following the planned Tolstoy path as a reflection of the objective laws of life, a signal of growing up and becoming an individual, mediated not so much by Tolstoy's directorates as by the vital force of Pushkin's thought. The story hardly gives grounds to believe that the hero will follow the "Tolstoy's" way; there is no reason for this. As there is no reason to assume that Bunin chose the path of Tolstoy for himself. Contrary to the essay narratives of The Liberation, the artistic text of Pure Monday showed that Bunin was closer to the philosophy of life affirmation than life denial. He seemed to "linger" along with his hero on the second "phase".

It remains not entirely clear how conscious and rationalistic the connection between The Liberation of Tolstoy and Pure Monday could be in Bunin's representation. The difference in the time of writing the essay and the story is about seven years; there may not be a direct and conscious dependence between them. However, given that the treatise bears the signs of Bunin's diary entries, that is, reflects the length of the process of thinking about Tolstoy's philosophy, the echoes of these "intramonological" reflections some time after the publication of the essay could give birth to artistic images in the creative consciousness of Bunin, which in such a 
perfect aesthetic form reflected the search of the philosophy of life, the philosophy of love and the philosophy of withdrawal-liberation by a mature writer. Bunin himself may not have been aware of the direct connection-coincidence between The Liberation of Tolstoy and Pure Monday, but the "psychology of creativity" pushes for such a comparison.

\section{References}

Averin, B.V. (2001). Zhizn' Bunina i zhizn' Arsen'eva: poetika vospominanii [The Life of Bunin and the Life of Arsen'ev: the poetics of memories], In I.A. Bunin: pro et contra. Saint-Petersburg, RKhGI, 651-657.

Bitsilli, P.M. (2000). Ivan Bunin. Osvobozhdenie Tolstogo. IMCA-Press. Paris, 1937 [Ivan Bunin. The Liberation of Tolstoy. IMCA-Press. Paris, 1937], In Bitsilli P.M. Tragediia russkoi kultury: Issledovaniia. Stat'i. Retsenzii [Bitsilli P.M. The tragedy of the Russian culture: Research. Articles. Reviews]. Moscow, Russkii put', 427-430.

Bunin, I.A. (2006-2007). Dumaia o Pushkine [Thinking about Pushkin], In Bunin I.A. Sobranie sochinenii: v 16 t. [Bunin I.A. Collected works, in 16 Vol.], 8. Moscow, Voskresenie, 7-11.

Bunin, I.A. (1996). Osvobozhdenie Tolstogo [The Liberation of Tolstoy], In Bunin I.A. Sobranie sochinenii: v 6 t. [Bunin I.A. Collected works, in 6 Vol.], 6. Moscow, Terra, 5-146.

Bunin, I.A. (2002). Chistyi ponedel'nik [Pure Monday], In Bunin I.A. Temnye allei [In Bunin I.A. Dark Alleys]. Moscow, Molodaia gvardiia, 206-218.

Garmash, E. (2004). O dvukh reministsentsiiakh v rasskaze I. Bunina "Chistyi ponedel'nik" [On two allusions in the story Pure Monday by Ivan Bunin], In Filologicheskie issledovaniia [Philological studies], 6. Donetsk, 3-9.

Dolgopolov, L.K. (1973). O nekotorykh osobennostiakh realizma pozdnego Bunina (opyt kommentaria k rasskazu "Chistyi ponedel'nik") [On some features of the realism of late Bunin (the experience of the review to the story Pure Monday)], In Russkaia literature [Russian literature], 2, 93-109.

Mikhailov, O.N. (2002). Ivan Tsarevich[Ivan Tsarevich], In Bunin I.A. Temnye allei [Bunin I.A. Dark Alleys]. Moscow, Molodaia gvardia, 3-12.

Nikolina, N.A. (1996). Lingvisticheskii analiz rasskaza I.A. Bunina "Chistyi ponedel'nik" [Linguistic analysis of the story Pure Monday by Ivan Bunin), In Russkaia literatura [Russian literature], 3, 79-85.

Romanenkova, M. (2014). Antroponimy kak kulturnyi component struktury rasskaza Ivana Bunina "Chistyi ponedel'nik" [Anthroponyms as a cultural component of the structure of the story Pure Monday by Ivan Bunin), In Grani kul'tury Serebrianogo veka: Sb. Nauchnykh statei [The Faces of Culture of the Silver age: Collection of scientific articles]. Vilnius, 126-138. 


\title{
Идеи-герои в рассказе И. Бунина \\ «Чистый понедельник»
}

\author{
О.В. Богданова \\ Санкт-Петербургский государственный \\ университет \\ Россия, 199034, Санкт-Петербург, \\ Университетская набережная, 7/9
}

В статье на основе сопоставления текстов рассказа «Чистый понедельник» (1944) и религиозно-философского трактата «Освобождение Толстого» (1937) предлагается новый взгляд на понимание философской структуры новеллы, входящей в иикл «Темные аллеи». В статье утверждается зависимость идейно-образной системы рассказа от философии смерти («философии ухода») Л.Н. Толстого. Автор работы доказывает, что если в основе сюжета рассказа лежит любовная история героев «он и она», то на уровне отражения философских идей, как показывает проводимое сопоставление, герои Бунина оказываются персонификацией абстрактной любви художника к мыслям и идеям писателей-предшественников. Образ главной героини «Чистого понедельника»- идея-олицетворение любви Бунина к философским взглядам позднего Толстого, образ героя - реализованное в персонаже отражение идей-представлений о мире А.С. Пушкина, его «онегинский тип». Столкновение различных жизненных философий становится «условием» несостоявщейся любви героев.

Ключевые слова: история русской литературы ХХ в., проза, И.А. Бунин, «Чистый понедельник», философская структура, система образов.

Научная специальность: 10.00.00 - филологические науки. 